\title{
Evaluation of potassium humate material in wood-plastic composite production
}

\author{
Nasır NARLIOĞLU ${ }^{1}$, Tufan SALAN²*, Eyyüp KARAOĞUL ${ }^{3}$, Mehmet Hakkı ALMA ${ }^{4}$ \\ ${ }^{1}$ Kahramanmaraş Sütçü İmam University, Technical Vocational School, Department of Material and \\ Material Processing, 46100, Kahramanmaraş, TURKEY \\ ${ }^{2}$ Kahramanmaraş Sütçü İmam University, Department of Materials Science and Engineering, 46040, \\ Kahramanmaraș, TURKEY \\ ${ }^{3}$ Harran University, Department of Food Engineering, 63300, Şanlıurfa, TURKEY \\ ${ }^{4}$ Kahramanmaraş Sütçü İmam University, Department of Forest Industry Engineering, 46040, \\ Kahramanmaraş, TURKEY \\ *Corresponding author: tufansalan@gmail.com
}

Received date: 26.10 .2017

Accepted date: 02.08 .2018

\begin{abstract}
Aim of study: The aim of the study was to investigate the usability of potassium humate material as an additive to improve some properties of wood-plastic composites.

Area of study: The fire retardancy and mechanic properties of the wood-plastic composites.

Material and Methods: The medium-density fiberboard (MDF) powder and high-density polyethylene (HDPE) granule mixture was pelletized by using a parallel twin-screw extruder. The obtained composite pellets were molded into boards via hot pressing method. Some mechanical, physical, thermal and fire properties of the produced boards were investigated. Moreover, the chemical properties of the composites were analyzed by using Fourier Transform Infrared (FTIR) spectroscopy.

Main results: The results showed that the addition of potassium humate increased the tensile and flexural strengths by $15 \%$ and $9 \%$, respectively. However, the water uptake and volumetric swelling of the composite samples increased from $1.15 \%$ up to $2.52 \%$ and from $3.2 \%$ to $5.77 \%$, respectively. LOI and linear burning rate tests indicated that the potassium humate addition increased the fire resistance of composite samples by $3 \% \mathrm{O}_{2}$ (LOI) while it improved the burning rate as being $6.62 \mathrm{~mm} / \mathrm{min}$ lower.

Research highlights: The addition of the potassium humate into the wood-plastic composites enhanced the fire, thermal and mechanical properties of the material to some extent.

Keywords: Potassium humate, polyethylene, composite, additives, fire properties, mechanical properties

\section{Ahşap-plastik kompozit üretiminde potasyum humat maddesinin}

\section{değerlendirilmesi}

Özet

Çalışmanın amacı: Bu çalışmanın amacı potasyum humat maddesinin ahşap-plastik kompozitlerin bazı özelliklerini geliştirmek için bir katkı maddesi olarak kullanılabilirliğinin araştırılmasıdır.

Çalışma alanı: Ahşap-plastik kompozitlerin yangın direnci ve mekanik özellikleri

Materyal ve Yöntem: Orta yoğunluklu lif levha (MDF) tozu ve yüksek yoğunluklu polietilen (HDPE) granülü karışımı paralel ikiz vidalı bir ektrüder kullanılarak pelet haline getirilmiştir. Elde edilen kompozit peletler sıcak presleme işlemi ile levha haline dönüştürülmüştür. Üretilen levhaların bazı mekanik, fiziksel, 1sıl ve yangın özellikleri araştırılmıştır. Dahası, kompozitlerin kimyasal özellikleri Fourier Dönüşümü Kızılötesi (FTIR) spektroskopisi kullanılarak analiz edilmiştir.

Sonuçlar: Sonuçlar potasyum humat eklenmesinin çekme ve eğilme dirençlerini sırasıyla $\% 15$ ve $\% 9$ artırdığını göstermiştir. Bununla birlikte, kompozit örneklerinin su alma ve hacimsel şişme oranları sırasıyla $\% 1,15$ 'ten $\% 2,52$ 'ye kadar ve $\% 3,2^{\prime}$ den $\% 5,77^{\prime}$ ye kadar artış göstermiş̧ir. LOI ve liner yanma hızı testlerine göre potasyum humat eklenmesi kompozit örneklerinin yangın direncini $\% 3 \mathrm{O}_{2}$ (LOI) arttırırken yanma hızını $6,62 \mathrm{~mm} / \mathrm{dk}$ daha düşük olacak şekilde iyileştirmiştir.

Araştırma vurgularl: Ahşap-plastik kompozitlere potasyum humat eklenmesi malzemenin yangın, termal ve mekanik özelliklerini belirli derecede geliştirmiştir.

Anahtar kelimeler: Potasyum humat, polietilen, kompozit, katkı maddeleri, yangın özellikleri, mekanik özellikler 


\section{Introduction}

Wood plastic composites (WPCs) basically consist of thermosets (e.g., epoxy and phenolic resins) or thermoplastics such as polyethylene (PE), polypropylene (PP) and polyvinyl chloride (PVC) and they are reinforced with lignocellulosic fibers including wood industry wastes such as MDF powder. Additionally, several additives were combined with plastic and fiber to improve properties of the composite material (Ashori, 2008; Félix et al., 2013; Ndiaye et al., 2008). WPCs have become very popular and environmentally attractive due to renewable wood filler and the recycled plastics in the last decade. They rapidly found their way into the market and employed in a large scale of applications from automotive, to furniture, to construction industries for windows, doors, decking, fencing, and decorative trims (Markarian, 2005; Panthapulakkal et al., 2006). WPCs products also play a role in developing a more sustainable future offering a wide range of advantages such as weather resistance, long service life, superior fungal resistance and lower maintenance over conventional bio-products such as pressuretreated lumber and naturally durable cedar or redwood (Altuntas et al., 2017a).

Even though WPCs have merits such as higher stiffness and dimensional stability as well as lower cost and water uptake, they still have demerits such as lower mechanical properties, exposure to biological attack under high humidity conditions, discoloration due to sunlight etc. in comparison with unfilled polyolefin itself. Thus, it is necessary to improve their physical and mechanical properties to increase the market share and meet the requirements in the wood composite panel industry. A variety of additives have been used in WPCs in order to increase their performance as well as to eliminate the weak features, to prolong their service life and to increase their resistance to physical external influences. These additives include coupling agents (compatibilizers), lubricants (waxes, antisticks, releasing agents and flow modifiers, colorants, antioxidants, UV absorbers, mineral fillers, fire retardant chemicals and biodegradation inhibitors (biocides). Coupling agents and the fire retardants are the most popular among them (Klyosov, 2007; Kim and Pal, 2010).

Physical and mechanical properties of WPC are mostly related to the interactions between the wood filler and the polymer matrix. These interactions could be developed by using a coupling agent as an additive. Usually, coupling agents improve the compatibility between hydrophilic lignocellulosic material and hydrophobic polymer material providing the formation of a single-phase composite structure (Kim and Pal, 2010; Wechsler and Hiziroglu, 2007). Interfacial adhesion between bio-fiber and polyolefin is an important issue for WPC processing and its performance. In order to improve the interfacial adhesion between bio-fiber and polyolefin matrix as well as some biological and physical properties, different kinds of compatibilizers such as isocyanates, maleic anhydride, silanes, etc. were used as coupling agents (Ibach and Clemons, 2006; Kim and Pal, 2010; Klyosov, 2007; Lu et al., 2005). The coupling agents can result in covalent bonds, secondary bonds (e.g., hydrogen bonds), Van der Waals' forces, molecular entanglement and mechanical interlocking ( $\mathrm{Lu}$ et al., 2000). However, the mechanical properties of WPC treated with the above-mentioned coupling agents are still lower than those of polyolefin itself (Çetin et al., 2014; Klyosov, 2007; Ndiaye and Tidjani, 2012). So far, there have been various struggles to find out the costeffective, eco-friendly and high performance coupling agents in WPC industry.

Another drawback of the applications of WPCs is their flammability. WPCs have a serious fire risk comparing the wood-based materials owing to the high heating value of polyolefins. Thus, fire retardancy is a very critical issue to widen the usage of WPC in the application areas requiring low fire risk materials. The most commonly used method is the addition of fire retardants for the improvement of the flame resistance of WPC materials. Until now, a wide range of fire retardants including inorganic compounds, halogenated compounds and phosphorous compounds have been used as an additive in WPCs (Kim and Pal, 2010). The fire retardants can be classified into two principal groups as passive or active. Passive fire 
retardants such as ammonium polyphosphate, zinc borate, antimony trioxide operate by removing fuel for flame spread or by retarding heat generation. On the other hand, active fire retardants inhibit or suppress combustion by using several mechanisms such as releasing water (e.g., magnesium hydroxide), forming nonflammable gases (smoke) to poison the flame (e.g., brominated compounds) and acting as char formers (e.g., ammonium polyphosphate) (Klyosov, 2007). Commonly used fire retardants are boric acid; phosphoric acid; zinc chloride and borate; aluminum trihydroxide; decabromodiphenyl oxide; ammonium phosphates and borates; ammonium sulfate and chloride; dicyanodiamide; antimony trioxide; sodium borate; magnesium dihydroxide, expandable graphite, carbon nanotubes, and mineral fillers (e.g., calcium carbonate, wollastonite, soapstone and talc) and so on (Fu et al., 2010; Huuhilo et al., 2010; Mngomezulu et al., 2014; Sain et al., 2004; Stark et al., 2010). Moreover, some of the fire retardants (e.g., zinc borate, antimony trioxide, magnesium hydroxide) were used together as synergists to improve the fire retardancy of WPC (Altuntas et al., 2017b).

Nowadays, the mechanical stability and the fire resistance are two important factors in the usage areas of WPC materials. For this reason, it is necessary to improve these properties by adding various additives. Although several fillers and additives have been widely used, composites containing organic fillers derived from renewable resources should be investigated on the account of environmental concerns at the end of its service life and the increasing costs of the synthetic additives. Moreover, some process complexities along with the costeffectiveness issues about the production may arise due to increasing ratio and number of the additives in WPC. In this context, potassium humate, a natural abundant material, was used as an additive in WPC to meet these two important necessities simultaneously in this study.

In previous studies, the potassium humate has been used as an additive in the production of superabsorbent nanocomposite (Shahid et al., 2012). For instance, Li et al.
(2008) prepared a novel potassium humateacrylic acid-acrylamide superabsorbent polymer from the reaction among leonardite potassium humate, acrylic acid and acrylamide by free radical initiating process. In another study, a new polyacrylamidebentonite composite with amine functionality was produced using direct polymerization with N,N'-methylenebisacrylamide as a crosslinking agent and potassium peroxydisulphate as an initiator followed by reaction with ethylenediammine. The prepared composite was modified by immobilizing humic acid and tested as an adsorbent to remove basic dyes from aqueous solutions (Anirudhan et al., 2009).

Humic acids and their salts are the natural organic materials obtained from different coal sources and they may be a significant alternative for the existing compatibilizers and fire retardants. Potassium humate (Figure 1) is an inexpensive, commercially available soluble salt of humic acid, containing a variety of components such as quinune, catechol, sugar, phenol, sugar moieties and functional groups (e.g., - $\mathrm{COOH},-\mathrm{OH},-\mathrm{NH}$, $-\mathrm{CHO},-\mathrm{COOH}, \quad-\mathrm{N}=\mathrm{C}$ and phenolics) (Stevenson, 1994).

In this study, different WPC formulations were prepared with the addition of potassium humate at different ratios. The mechanical, physical, chemical and fire properties of the produced WPC samples were investigated by using different methods. Although potassium humate was used as an additive in adsorbents, hydrogel nanocomposites and soils, to the best of our knowledge, there is any study reported on the usage of potassium humate as an additive in lignocellulosic material-filled polymer composites.

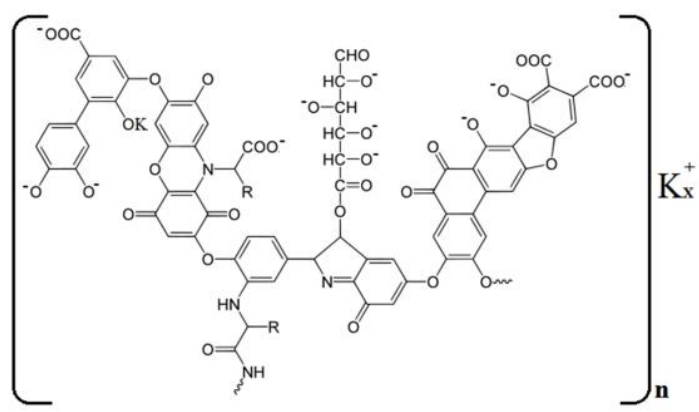

Figure 1. Example of a typical potassium humate 


\section{Materials and Method \\ Materials}

In the manufacturing processes, medium density fiberboard (MDF) powders were used as the lignocellulosic filler. MDF powders, obtained from a local furniture manufacturer, were screened into the size of 60 mesh and dried in an oven at $103 \pm 2{ }^{\circ} \mathrm{C}$ overnight. High-density polyethylene (HDPE; S0464) was provided from Petkim Co. (Turkey). Potassium humate was provided from Platin Chemistry Co. (Turkey). Table 1 demonstrates the properties of potassium humate used as an additive material. The potassium humate was firstly diluted with water and then mixed thoroughly with MDF powders. Finally, the mixture was dried in an oven at $103 \pm 2{ }^{\circ} \mathrm{C}$ until the constant weight.

Table 1. Properties of potassium humate used in the study

\begin{tabular}{lc}
\hline Ingredients & wt\% \\
\hline Total organic matter & 25 \\
\hline Total humic and fulvic acid & 70 \\
\hline Water-soluble potassium oxide & 3 \\
$\left(\mathrm{~K}_{2} \mathrm{O}\right)$ & \\
\hline The maximum humidity & 20 \\
\hline Boron & $100 \mathrm{ppm}$ \\
\hline $\mathrm{pH}$ & $9-10$ \\
\hline
\end{tabular}

\section{Production of Composites}

As shown in Table 2, three different formulations were prepared from various ratios of HDPE, MDF and potassium humate along with pure HDPE and a composite sample without potassium humate for the comparison. The prepared mixtures were primarily pelletized by using a twin screw extruder (Gülnar Machinery Co.) with an $\mathrm{L} / \mathrm{D}$ ratio of 44 . The temperature profile was set between $90-175{ }^{\circ} \mathrm{C}$ for extruder zones at a screw rotation speed of $50 \mathrm{rpm}$. The pellets were dried in an oven at $103 \pm 2{ }^{\circ} \mathrm{C}$ until the constant weight prior to the molding process. The dried pellets were then molded into the composite boards having a size of $250 \times 250$ x $2 \mathrm{~mm}$ by using a hydraulic hot press (Carver) at $190{ }^{\circ} \mathrm{C}$ for $5 \mathrm{~min}$. Finally, the produced boards were cooled to ambient temperature under a cold press. All the test samples were prepared from the compression-molded boards according to the relevant standard and conditioned in a climatic test chamber (Nüve) at $65 \pm 5 \%$ relative humidity and $23 \pm 2{ }^{\circ} \mathrm{C}$ temperature for 7 days.

Table 2. Formulations used for the production of composite samples

\begin{tabular}{cccc}
\hline $\begin{array}{c}\text { Sample } \\
\text { code }\end{array}$ & $\begin{array}{c}\text { HDPE } \\
\text { (wt\%) }\end{array}$ & $\begin{array}{c}\text { Potassium } \\
\text { humate } \\
\text { (wt\%) }\end{array}$ & $\begin{array}{c}\text { MDF } \\
\text { powder } \\
\text { (wt\%) }\end{array}$ \\
\hline HDPE & 100 & 0 & 0 \\
\hline W40 & 60 & 0 & 40 \\
\hline H5 & 55 & 5 & 40 \\
\hline H10 & 50 & 10 & 40 \\
\hline H15 & 45 & 15 & 40 \\
\hline
\end{tabular}

\section{Characterization of Composites}

Mechanical properties of the composites were measured using Zwick/Roell test equipment. Flexural, tensile and impact strengths were determined according to ASTM D790, ASTM D638, and ASTM D256, respectively. Limiting Oxygen Index (LOI) was tested according to ASTM D2863 standard using a cylindrical chamber (Dynisco) while the burning test was carried out according to ASTM D635 standard in a horizontal-vertical flame chamber (Atlas HVUL2). Short-term water adsorption and thickness swelling test were carried out by immersing the composite samples in distilled water at $25{ }^{\circ} \mathrm{C}$ for $24 \mathrm{~h}$. Thermo-gravimetric analyses (TGA) of the composites were carried out via Shimadzu TGA-50 analyzer. The analysis of the samples was performed from 25 to $800{ }^{\circ} \mathrm{C}$ at a heating rate of 20 ${ }^{\circ} \mathrm{C} / \mathrm{min}$ under a nitrogen flow of $50 \mathrm{~mL} / \mathrm{min}$ after samples were completely dried in an oven at $103 \pm 2{ }^{\circ} \mathrm{C}$ for $6 \mathrm{~h}$. Fourier-transform infrared (FTIR) spectroscopy was used to determine the chemical interaction of potassium humate with MDF powder and HDPE. The FTIR measurements of composites and potassium humate were carried out with the Perkin-Elmer 400 Spectrometer in the wavenumber range of $400-4000 \mathrm{~cm}^{-1}$ by using potassium bromide $(\mathrm{KBr})$ technique. One $\mathrm{mg}$ of potassium humate was homogeneously mixed with 200 $\mathrm{mg} \mathrm{KBr}$ in a mortar and pressed into pellet forms. 


\section{Results and Discussion \\ Mechanical Tests}

Figure 2 demonstrates the tensile strength and modulus of composite boards with and without potassium humate. As clearly shown in this figure, composites treated with potassium humate had a higher tensile strength than that of control sample without potassium humate. This could be attributed to the enhanced interfacial interaction between HDPE and wood. However, the tensile strength of the composite samples was decreased with the increasing ratio of potassium humate. Similar results were obtained in a study about WPC produced by using HDPE, wood and different kinds of functionalized polyolefins. In general, the tensile strength of composite increases significantly with the addition compatibilizers at the lower loadings, but it tended to decrease or level off at the high levels of concentration (Lai et al., 2003; Lu et al., 2005).

This phenomenon was explained due to critical interfacial concentration as an important parameter. This parameter defines the optimum concentration of an interfacial agent (i.e., compatibilizer) in the interface of two immiscible components to determine the efficacy of compatibilization. The optimum interfacial concentration is the minimum value of interfacial saturation of a compatibilizer agent in the dispersed phase. When the concentration is above or below this critical value, the compatibilizer is not effective in improving the compatibilization of the polymer blends (Liu et al., 2003).

The tensile modulus of MDF powder/HDPE composite increased with the addition of potassium humate. With the addition of $5 \mathrm{wt} \%$ potassium humate into the composite board, the tensile modulus was determined as about $838 \mathrm{MPa}$ and then became almost constant with further increment in the potassium humate content.

In addition, tensile modulus of the whole composites was higher than that of HDPE composite itself. It has been reported that the modulus of elasticity values of lignocellulosic composites firstly increased with increasing ratio of natural fiber added into the polymer matrix and then decreased after further addition. Generally, wood-based fibers have an average tensile strength of 0.5 $1.5 \mathrm{GPa}$ and a modulus of 10-80 GPa. Thus, wood-based fibers increase the modulus of elasticity of the polymer composites, which they are added into (Bledzki et al., 1998; Hargitai et al., 2008; Khoathane et al., 2008). Finally, the tendency of all the mechanical properties of the composite samples was found to be very similar to each other.

The flexural strengths and modulus of MDF powder/HDPE composites treated with and without potassium humate were given in Figure 3. With the addition of $5 \mathrm{wt} \%$ of potassium humate into the composite, the flexural strength was found a little lower (33.49 $\mathrm{MPa})$ compared to the composite without potassium humate $(30.74 \mathrm{MPa})$. About $9 \%$ increment in the strength was recorded due to the addition of $5 \%$ potassium

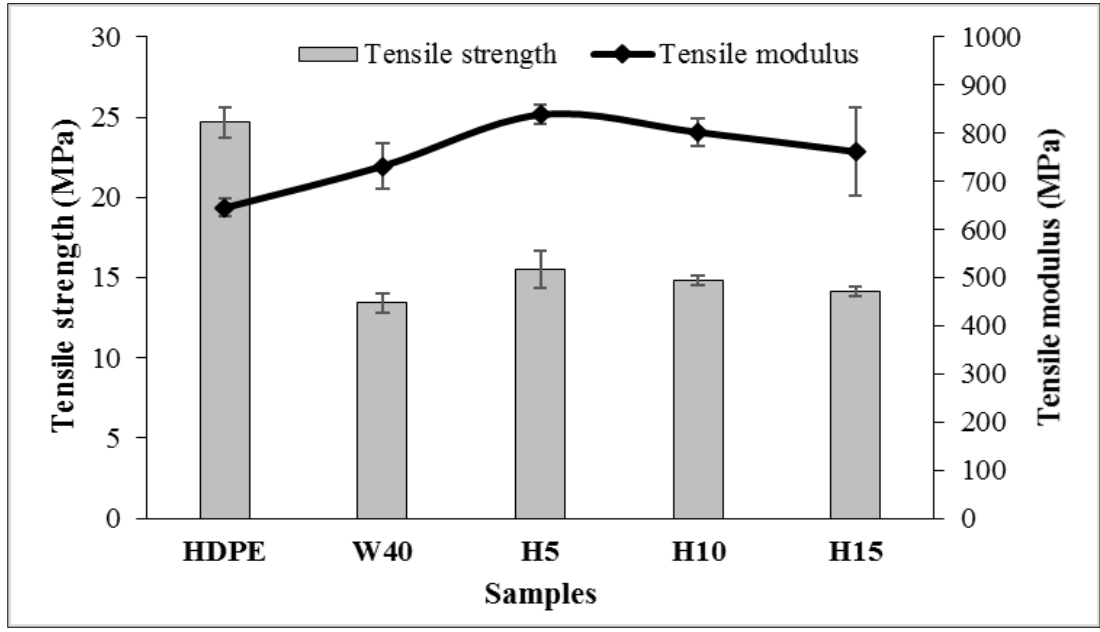

Figure 2. Tensile strength and tensile modulus of composite samples 
humate into the board sample in comparison with the reference sample. The highest flexural strength (ca. $33 \mathrm{MPa}$ ) was determined for $5 \%$ potassium humate added sample and then it slightly decreased with increasing potassium humate addition from 5 to $15 \%$.

Özmen et al. (2014) reported that the flexural strength and modulus values of composites increased with the increasing ratio of the medium density fiberboard (MDF) powder in MDF/PP polymer composites. Moreover, some other researchers also reported that the flexural strength and flexural modulus values of composites increased due to the increase of fiber ratio in natural fiber-added composites (Bengtsson et al., 2007; Basiji et al., 2010).

The flexural modulus of the MDF powder/HDPE composites was improved with increasing potassium humate content. The flexural modulus of the potassium humate added composites was found as 1993 $\mathrm{MPa}, 1814 \mathrm{MPa}$ and $1785 \mathrm{MPa}$ for 5, 10, 15 wt $\%$ potassium humate, respectively. However, the composites without potassium humate had a lower modulus of $1676 \mathrm{MPa}$. It was important to notice that the tendency of flexural modulus was similar to that of flexural strength as expected. Furthermore, the modulus of the pure HDPE composite was considerably lower than those of composite boards with and without potassium humate.

Table 3 depicts the impact strength of composite boards treated with and without potassium humate. It was evident from the table that the impact strength decreased somewhat with the addition of potassium humate for all the samples compared to the neat HDPE board and W40. This phenomenon could be ascribed to the filler effect of potassium humate. The impact strengths of the potassium humate added composites were lower compared to board without potassium humate.

Table 3. The impact strength of composite samples

\begin{tabular}{lcc}
\hline Samples & $\begin{array}{c}\text { Impact strength } \\
\left(\mathbf{k J} / \mathbf{m}^{2}\right)\end{array}$ & $\begin{array}{c}\text { Standard } \\
\text { deviation }\end{array}$ \\
\hline HDPE & 193.41 & 3.57 \\
\hline W40 & 3.76 & 0.27 \\
\hline H5 & 2.93 & 0.15 \\
\hline H10 & 3.23 & 0.26 \\
\hline H15 & 2.91 & 0.13 \\
\hline
\end{tabular}

When the potassium humate added composites compared with each other, it was noted that the impact strength of the composites firstly slightly increased with an increase in potassium humate content, and then slightly decreased with the further increase in potassium humate content. This can be explained by the fact that MDF powder containing $12 \%$ adhesive in advance reduced the ability of the composite to absorb energy during crack propagation and also resulted in high-stress concentration regions (Nourbakhsh and Ashori, 2009).

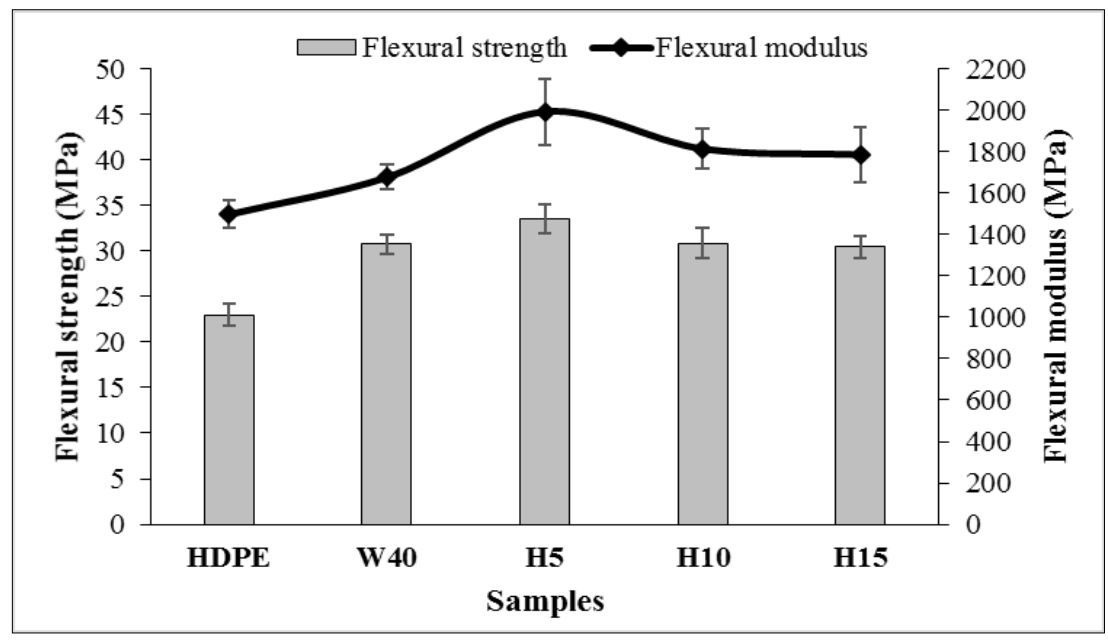

Figure 3. Flexural strength and flexural modulus of composite samples 
Therefore, in order to obtain sufficient impact strength, an optimum bonding level was imperative.

\section{Fire Retardancy of Composites}

Figure 4 demonstrates the linear burning rate and LOI index of composite boards. As shown in this figure, the addition of potassium humate into the board clearly reduced the linear burning rate. With the addition of potassium humate at the percentages of 5,10 and 15 , the linear burning rates were determined as 13.86 $\mathrm{mm} / \mathrm{min}, 13.43 \mathrm{~mm} / \mathrm{min}$ and $12.74 \mathrm{~mm} / \mathrm{min}$, respectively, in comparison with the composite sample without potassium humate (19.36 $\mathrm{mm} / \mathrm{min}$ ) and HDPE composite $(25.17 \mathrm{~mm} / \mathrm{min})$ itself.

Garcia et al. (2009) produced wood plastic composites with HDPE and wood fibers by adding additives such as fire retardants and light stabilizers to improve properties like fire retardancy and durability performance. They reported that when neat HDPE was burnt, the polymer started the dripping as soon as the material was in contact with the flame and the integrity of the material was completely lost immediately. However, the addition of wood fibres and other fire retardants improved such behaviour and the composite maintained its integrity during the burning.

Moreover, several author reported that the fire retardants significantly improved the fire properties of the composites by slowing down the burning rate of the polymer part and preserving the lignocellulosic part of the polymer composites (Stark et al., 2010; Chapple and Anandjiwala, 2010; Nikolaeva, 2011; Pan et al., 2014).

However, for our study it was unclear whether the obtained improvements in fire characteristics of the composite samples were due to the reduction of the HDPE ratio or the addition of potassium humate into formulation. Because, the main source of the combustion problem in the WPCs is the polymer matrix.

The LOI value of composite boards increased relatively with increasing amount of potassium humate. However, there was no significant difference in LOI values amongst composite boards with various potassium humate ratios. Moreover, all the composite samples with potassium humate showed higher LOI value when compared to that of HDPE and W40 composite.

Consequently, it could be revealed that the addition of potassium humate evidently increased the fire retardancy of MDF powder/HDPE composite boards. Finally, the effects of potassium humate treatment on mechanical properties were much more pronounced compared to those of the effects potassium humate on the fire retardancy properties of the boards.

\section{TGA Analysis of Composites}

Figure 5 illustrates the thermal degradation curves of composites samples along with pure HDPE. It was evident from this figure that the initial decomposition

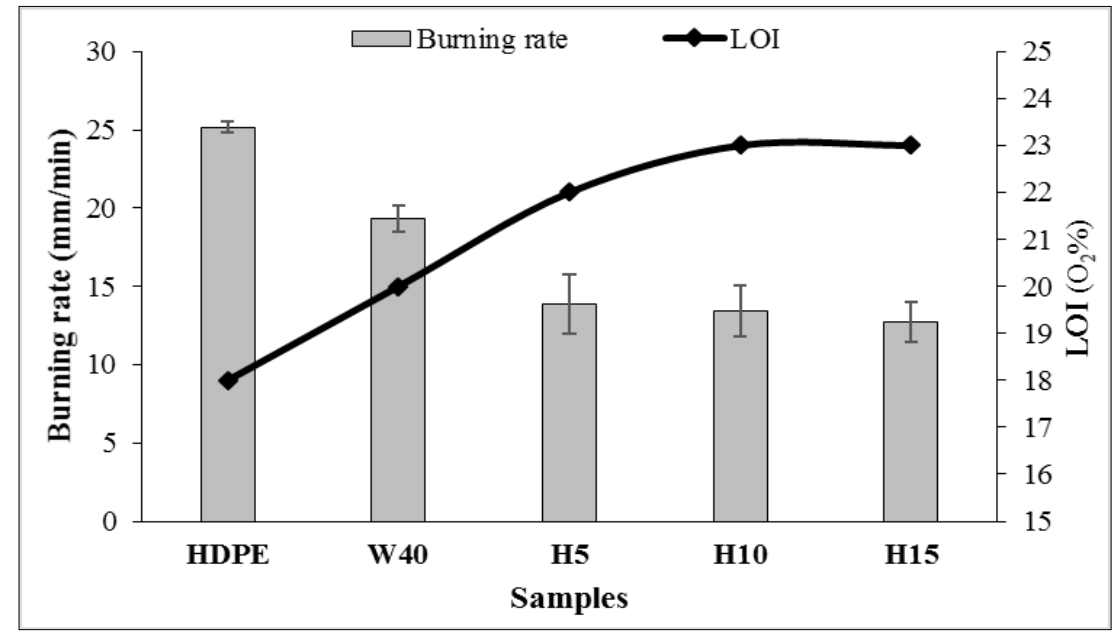

Figure 4. Linear burning rate and LOI results of composite samples 
temperature of composites decreased by about $30{ }^{\circ} \mathrm{C}$ with the addition of potassium humate in the temperature range of $270-400$ ${ }^{\circ} \mathrm{C}$, that was the region in which wood polymers decomposed rapidly.

According to the results obtained from TGA of the wood, it was reported that the degradations below $400{ }^{\circ} \mathrm{C}$ are caused by the deterioration of the wood components. For example; hemicelluloses, lignin, cellulose and extractives degraded at $150-350{ }^{\circ} \mathrm{C}, 350$ $500{ }^{\circ} \mathrm{C}$, and $275-350{ }^{\circ} \mathrm{C}$ temperature ranges, respectively (Kim et al., 2006).

However, in the region of $400-520{ }^{\circ} \mathrm{C}$, which was the degradation range of HDPE, the mass loss of composites substantially decreased due to the increased thermal stability of polymer material in the composite via addition of potassium humate. In this range, the maximum mass loss rate was recorded at the temperature of about $480{ }^{\circ} \mathrm{C}$ from the DrTGA curves. The mass loss of the composite samples reduced by about 7 $15 \%$ with the addition of potassium humate compared to the sample W40 in this region. When the thermal properties of HDPE were examined, it was obvious that TGA curve composed of a single degradation region. The degradation of the polymer was usually rapid at the temperatures between 400-500 ${ }^{\circ} \mathrm{C}$ and it loses $99 \%$ of its mass. The maximum weight loss in the structure was in the range of about $460-465{ }^{\circ} \mathrm{C}$ (Contat-Rodrigo et al., 2002).

Consequently, the amount of the residues of the samples along with total weight loss

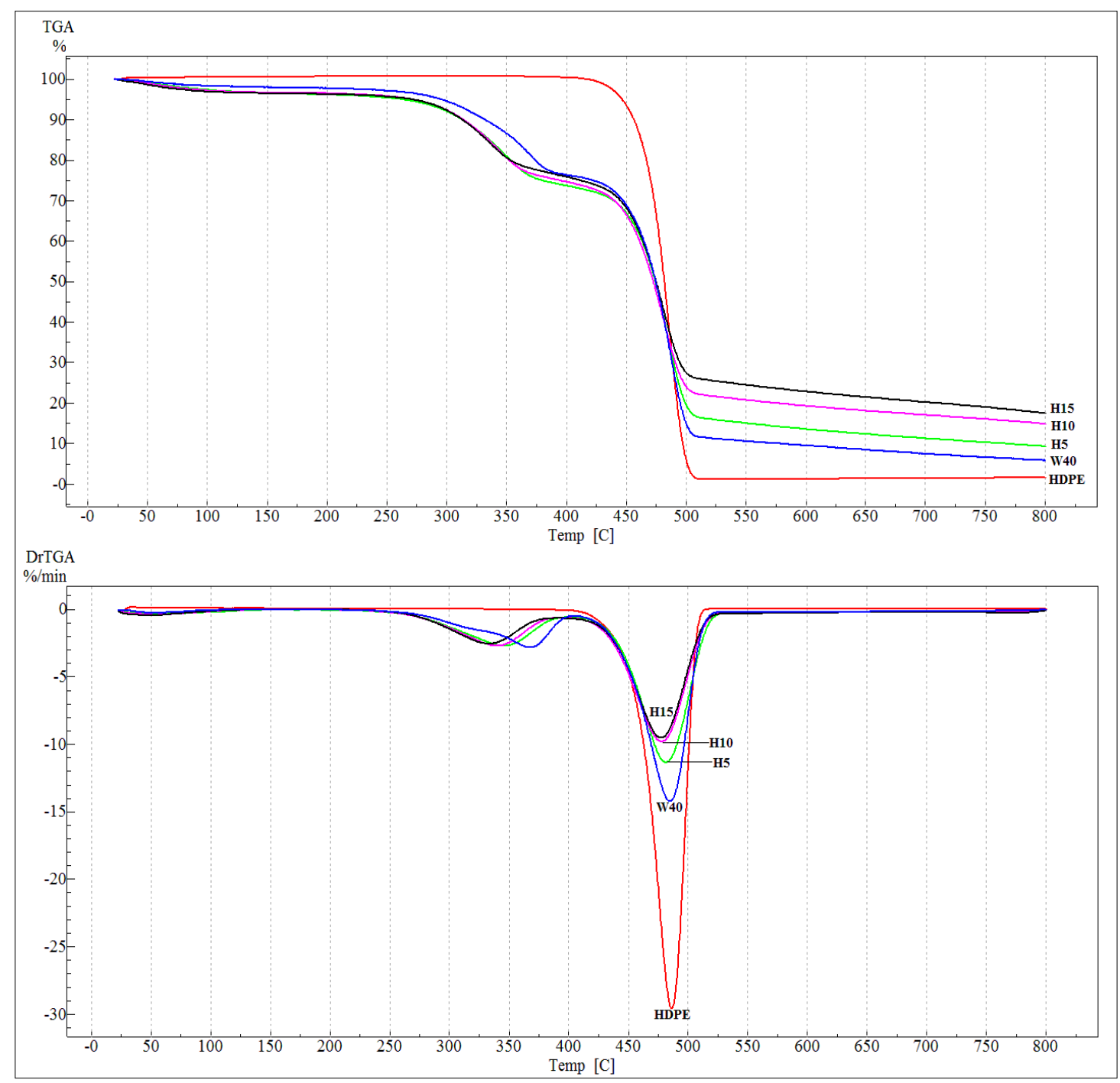

Figure 5. TGA and DrTGA curves of composite samples 
also showed that the addition of the potassium humate significantly increased the thermal stability of the composites by preserving polymer matrix from the heat. In previous studies, the addition of lignocellulosic filler or inorganic additives affected the thermal degradation properties of material in different ways (positively or negatively) due to the diversified thermal characteristics of additives (Ayrilmis et al., 2014; Altuntas et al., 2017b; Koohestani et al., 2017). However, it has been also determined that the thermal properties of the composite could be improved by applying chemical modification processes on the lignocellulosic materials (Çetin et al., 2015).

\section{Water Absorption Tests}

Table 4 indicates the effects of potassium humate addition on the volumetric swelling and water uptake capacity of composites samples with and without potassium humate. As depicted from this table, the swelling ratio of the composite increased about $3 \%$ with the addition of $15 \%$ potassium humate. Although there was no significant increase in the swelling ratio when the amount of potassium humate increased from 5 to $15 \%$. About $1 \%$ increment in the swelling was determined for $15 \%$ potassium humate added sample. Moreover, there was no significant difference in the swelling percentages determined for 5 and $10 \%$ potassium humate added samples.

That results showed that the small amount of potassium humate should be added to the wood plastic composite to some extent in order to stabilize the dimensions under high humidity conditions.

Table 4. Volumetric swelling and water uptake percentages of composite samples

\begin{tabular}{ccc}
\hline Samples & $\begin{array}{c}\text { Volumetric } \\
\text { swelling }(\boldsymbol{\%})\end{array}$ & $\begin{array}{c}\text { Water uptake } \\
(\boldsymbol{\%})\end{array}$ \\
\hline \multirow{2}{*}{ W40 } & 3.16 & 1.15 \\
& $(0.97)^{*}$ & $(0.32)$ \\
\hline \multirow{2}{*}{$\mathrm{H} 5$} & 4.39 & 1.49 \\
& $(0.91)$ & $(0.14)$ \\
\hline \multirow{2}{*}{ H10 } & 4.83 & 1.67 \\
& $(0.76)$ & $(0.17)$ \\
\hline \multirow{2}{*}{ H15 } & 5.77 & 2.52 \\
& $(0.88)$ & $(0.36)$ \\
\hline
\end{tabular}

*Standard deviation
It was obvious from the table that the water uptake percentage relatively increased when the amount of potassium humate increased from 0 to $15 \%$. The highest amount of water uptake (i.e., an increment of about $1.5 \%$ ) was found with the addition of $15 \%$ of potassium humate. This phenomenon also revealed that the addition of potassium humate should be adjusted by considering the other properties.

On the other hand, the obtained results came into conflict with the previous literature data available. Because the water absorption phenomenon in WPCs is normally related with the hydrophilic nature of wood fibers. The voids in the wood fibers could be occupied by using polymer and or a filler such as nanoclay to decrease the available space for water absorption in the composite. Moreover, if a chemical compatibilization could be generated between fiber and polymer, this would cause a decrease in the size of the interface area reducing the water absorption through this layer into inner sides of the composite (Franco-Marquès et al., 2011; Deka and Maji, 2010).

However, in the case of potassium humate the water uptake capacity of the samples relatively increased with the addition of humic substance. The obtained water uptake results in our study were assigned to the hydrophilic sites of the humic substances. They are important additives in soil science due to their function in plant growth by enhancing the structure, porosity, cation and anion exchange capacity of soil, chelation of mineral elements and most importantly water holding capacity (Khaled and Fawy, 2011; Eyheraguibel, 2008).

Thus, the addition of potassium humate into composite material weakened the structure relatively against water, while it enhanced several properties of the composite samples. Therefore, the usage of the potassium humate as an additive in WPCs may limit the usage of material in the high humidity applications such as outdoor flooring near the sea and the pool sides.

\section{FTIR Spectroscopy}

Figure 6 shows FTIR spectra of composite samples with and without potassium humate. Table 5 also lists the explanations of the wavenumbers along with 


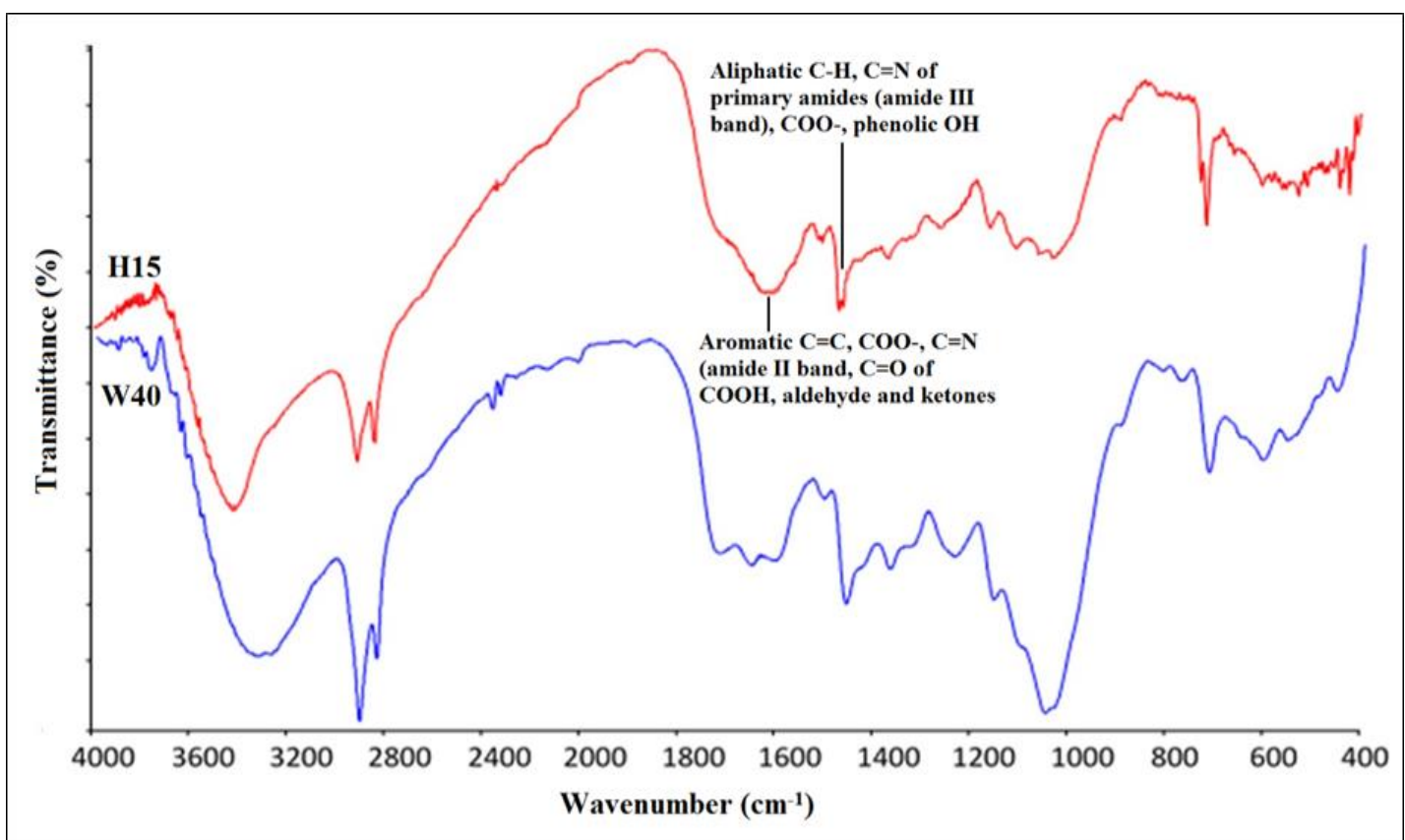

Figure 6. FTIR spectra of composites with (H15) and without (W40) potassium humate

determined functional groups. In the FTIR spectra of the composite samples, the peaks at $2910 \mathrm{~cm}^{-1}, 2840 \mathrm{~cm}^{-1}, 1450 \mathrm{~cm}^{-1}$ and 715 $\mathrm{cm}^{-1}$ were assigned to the characteristic groups in the polyethylene structure, namely $\mathrm{CH}_{2}$ asymmetric stretching, $\mathrm{CH}_{2}$ symmetric stretching, $\mathrm{CH}_{2}$ bending deformation and $\mathrm{CH}_{2}$ rocking deformation, respectively. Moreover, several peaks were originated from the cellulose, hemicellulose and lignin compounds of wood fibers in the composite structure. Several studies have been explained the FTIR spectra and reported functional groups of the wood filler in the WPCs (Altuntaş et al., 2017a; Wei et al., 2013; Fabiyi et al., 2011). In the FTIR analysis, the possible bonds between the potassium humate and wood fiber or polyethylene in the composite structures were investigated. Consequently, the following findings were obtained from spectra of composite samples with and without potassium humate. The wide bands in the regions of $3700-3100 \mathrm{~cm}^{-1}$ and 2920 $2840 \mathrm{~cm}^{-1}$ were attributed to $-\mathrm{OH}$ groups and aliphatic $\mathrm{C}-\mathrm{H}$ stretching, respectively. It should be noted that $-\mathrm{OH}$ transformation bands were observed between 1420 and 1260 $\mathrm{cm}^{-1}$. Also, two ester bands occurred between 1360 and $1075 \mathrm{~cm}^{-1}$, showing possible reaction of $-\mathrm{COOH}$ groups of potassium humate with -OH groups of the wood fibers in MDF powder. In addition, it could be realized that the $\mathrm{H} 15$ spectrum strongly changed at about $1700 \mathrm{~cm}^{-1}$ wavenumber due to -COO- deformation bands based on the possible interactions between potassium humate and wood fibers (Senesi et al., 2003; Tatzber et al., 2007).

\section{Conclusion}

Potassium humate was used as a filler material in MDF powder/HDPE composite board production. The findings showed that potassium humate had a positive effect on the tensile and flexural strength and their modulus of elasticity as well as fire retardancy properties to some extent. However, the impact strength slightly reduced with the addition of potassium humate. FTIR study demonstrated that there might be esterification type of interactions between cellulose-lignin complex in the wood fiber and potassium humate. Furthermore, potassium humate addition into composite boards increased water uptake and volumetric swelling due to water soaking in the negative direction. Therefore, so as to provide the best performance in mechanical and physical properties the optimum level of 
Table 5. FTIR spectra assignments of composite samples H15 and W40

\begin{tabular}{cl}
$\begin{array}{c}\text { Wavenumber } \\
\left(\mathbf{c m}^{-1}\right)\end{array}$ & \multicolumn{1}{c}{ Explanation } \\
\hline $3700-2200$ & $\begin{array}{l}\mathrm{OH}, \text { small contributions can be derived from }-\mathrm{NH}_{3}{ }^{+},-\mathrm{NH}_{2}{ }^{+},-\mathrm{CO}- \\
\mathrm{NH}_{2},-\mathrm{CO}-, \mathrm{NH} \text { and } \mathrm{S}-\mathrm{H}\end{array}$ \\
\hline $2920-2840$ & Aliphatic groups \\
\hline 1700 & $\begin{array}{l}\mathrm{C}=\mathrm{O} \text { vibrations of carboxyl groups, aldehydes and ketones, } \\
\text { contributions can be derived from carbonyl groups of esters }\end{array}$ \\
\hline 1620 & $\begin{array}{l}\mathrm{C}=\mathrm{O} \text { of amide groups and } \mathrm{C}=\mathrm{O} \text { of quinone ketones, contributions } \\
\text { can be derived from nitrates }\left(\mathrm{R}-\mathrm{O}-\mathrm{NO}_{2}\right), \text { nitrites }(\mathrm{R}-\mathrm{O}-\mathrm{NO})\end{array}$ \\
\hline 1550 & $\mathrm{~N}-\mathrm{H}, \mathrm{C}=\mathrm{N}$, and $\mathrm{C}=\mathrm{C}$ \\
\hline 1500 & Aliphatic $\mathrm{C}-\mathrm{H}$ \\
\hline 1420 & $\begin{array}{l}\mathrm{C}=\mathrm{N} \text { of primary amides, contributions are possibly from groups like } \\
-\mathrm{COO}-\end{array}$ \\
\hline 1360 & $\mathrm{CO}-\mathrm{CH}{ }_{3}$ and possibly from nitrate \\
\hline 1260 & $\begin{array}{l}\mathrm{Nitrates}\left(\mathrm{R}-\mathrm{O}-\mathrm{NO}{ }_{2}\right),=\mathrm{C}-\mathrm{O}-\mathrm{C} \text { groups, and possibly } \mathrm{P}=\mathrm{O} \text { vibrations, } \\
\mathrm{C}-\mathrm{O} \text { of phenolic groups }\end{array}$ \\
\hline 1075 & $\mathrm{C}-\mathrm{O}$ of alcohols and $\mathrm{C}-\mathrm{O}$ of aliphatic ethers \\
\hline 900 & $\mathrm{R}_{2} \mathrm{C}=\mathrm{CH}{ }_{2}$ groups \\
\hline
\end{tabular}

potassium humate content found to be as 5 wt $\%$, while the fire retardancy and thermal stability properties were better at the humic material level of $15 \mathrm{wt} \%$.

\section{References}

Altuntas, E., Yilmaz, E., Salan, T., Alma, M.H. (2017a). Biodegradation properties of wood-plastic composites containing high content of lignocellulosic filler and zinc borate exposed to two different brown-rot fungi. BioResources, 12(4), 7161-7177.

Altuntas, E., Narlioglu, N., Alma, M.H. (2017b). Investigation of the fire, thermal, and mechanical properties of zinc borate and synergic fire retardants on composites produced with PP-MDF wastes. BioResources, 12(4), 6971-6983.

Anirudhan, T.S., Suchithra, P.S., Radhakrishnan, P. G. (2009). Synthesis and characterization of humic acid immobilized-polymer/bentonite composites and their ability to adsorb basic dyes from aqueous solutions. Applied Clay Science, 43(3-4), 336-342.

Ashori, A. (2008). Wood-plastic composites as promising green-composites for automotive industries! Bioresource Technology, 99(11), 4661-4667.
Ayrilmis, N., Dundar, T., Kaymakci, A., Ozdemir, F., Kwon, J.H. (2014). Mechanical and thermal properties of wood-plastic composites reinforced with hexagonal boron nitride. Polymer Composites, 35(1), 194-200.

Basiji, F., Safdari, V., Nourbakhsh, A., Pilla, S. (2010), The effects of fiber length and fiber loading on the mechanical properties of wood-plastic (polypropylene) composites. Turkish Journal of Agriculture and Forestry, 34(3), 191-196.

Bengtsson, M., Le Baillif, M., Oksman, K. (2007), Extrusion and mechanical properties of highly filled cellulose fibrepolypropylene composites. Composites Part A: Applied Science and Manufacturing, 38(8), 1922-1931.

Bledzki, A.K., Reihmane, S.A., Gassan, J. (1998). Thermoplastics reinforced with wood fillers: a literature review. PolymerPlastics Technology and Engineering, 37(4), 451-468.

Chapple, S., Anandjiwala, R. (2010). Flammability of natural fiber-reinforced composites and strategies for fire retardancy: a review. Journal of Thermoplastic Composite Materials, 23(6), 871-893. 
Contat-Rodrigo, L., Ribes-Greus, A., Imrie, C.T. (2002). Thermal analysis of high-density polyethylene and low-density polyethylene with enhanced biodegradability. Journal of Applied Polymer Science, 86(3), 764-772.

Çetin, N.S., Özmen, N., Narlığlu, N., Çavuş, V. (2014). Effect of bark flour on the mechanical properties of HDPE composites. Usak University Journal of Material Sciences, 3(1), 23-32.

Çetin, N.S., Çetin, N., Harper, D.P. (2015). Vinyl acetate-modified microcrystalline cellulose-reinforced HDPE composites prepared by twin-screw extrusion. Turkish Journal of Agriculture and Forestry, 39(1), 39-47.

Deka, B.K., Maji, T.K. (2010). Effect of coupling agent and nanoclay on properties of HDPE, LDPE, PP, PVC blend and Phargamites karka nanocomposite. Composites Science and Technology, 70(12), 1755-1761.

Eyheraguibel, B., Silvestre, J., Morard, P. (2008). Effects of humic substances derived from organic waste enhancement on the growth and mineral nutrition of maize. Bioresource Technology, 99(10), 4206-4212.

Fabiyi, J.S., McDonald, A.G., Morrell, J.J., Freitag, C. (2011). Effects of wood species on durability and chemical changes of fungal decayed wood plastic composites. Composites Part A: Applied Science and Manufacturing, 42(5), 501510.

Félix, J.S., Domeño, C., Nerín, C. (2013). Characterization of wood plastic composites made from landfill-derived plastic and sawdust: Volatile compounds and olfactometric analysis. Waste Management, 33(3), 645-655.

Franco-Marquès, E., Méndez, J.A., Pèlach, M.A., Vilaseca, F., Bayer, J., Mutjé, P. (2011). Influence of coupling agents in the preparation of polypropylene composites reinforced with recycled fibers. Chemical Engineering Journal, 166(3), 1170-1178.

Fu, S., Song, P., Yang, H., Jin, Y., Lu, F., Ye, J., Wu, Q. (2010). Effects of carbon nanotubes and its functionalization on the thermal and flammability properties of polypropylene/wood flour composites. Journal of Materials Science, 45(13), 3520-3528.

Hargitai, H., Rácz, I., Anandjiwala, R.D. (2008). Development of hemp fiber reinforced polypropylene composites. Journal of Thermoplastic Composite Materials, 21(2), 165-174.

Huuhilo, T., Martikka, O., Butylina, S., Kärki, T. (2010). Mineral fillers for wood-plastic composites. Wood Material Science and Engineering, 5(1), 34-40.

Ibach, R.E., Clemons, C.M. (2006). Effect of acetylated wood flour or coupling agent on moisture, UV, and biological resistance of extruded woodfiber-plastic composites. Wood Protection, 139-147.

Garcia, M., Hidalgo, J., Garmendia, I., García-Jaca, J. (2009). Wood-plastics composites with better fire retardancy and durability performance. Composites Part A: Applied Science and Manufacturing, 40(11), 1772-1776.

Khaled, H., Fawy, H.A. (2011). Effect of different levels of humic acids on the nutrient content, plant growth, and soil properties under conditions of salinity. Soil and Water Research, 6(1), 21-29.

Khoathane, M.C., Vorster, O.C., Sadiku, E.R. (2008), Hemp fiber-reinforced 1pentene/polypropylene copolymer: the effect of fiber loading on the mechanical and thermal characteristics of the composites, Journal of Reinforced Plastics and Composites, 27(14), 15331544.

Kim, J.P., Yoon, T.H., Mun, S.P., Rhee, J.M., Lee, J.S. (2006). Woodpolyethylene composites using ethylenevinyl alcohol copolymer as adhesion promoter. Bioresource Technology, 97(3), 494-499.

Kim, J.K., Pal, K. (2010). Recent advances in the processing of wood-plastic composites (Vol. 32). Springer Science \& Business Media, Berlin.

Klyosov, A.A. (2007). Wood-plastic composites. New Jersey, NJ: John Wiley \& Sons.

Koohestani, B., Ganetri, I., Yilmaz, E. (2017). Effects of silane modified minerals on mechanical, microstructural, thermal, and rheological properties of 
wood plastic composites. Composites Part B: Engineering, 111, 103-111.

Lai, S.M., Yeh, F.C., Wang, Y., Chan, H.C., Shen, H.F. (2003). Comparative study of maleated polyolefins as compatibilizers for polyethylene/wood flour composites. Journal of Applied Polymer Science, 87(3), 487-496.

Li, W., Wang, J., Zou, L., Zhu, S. (2008). Synthesis and characterization of potassium humate-acrylic acidacrylamide hydrogel. Journal of Polymer Research, 15(6), 435-445.

Liu, W., Wang, Y.J., Sun, Z. (2003). Effects of polyethylene-grafted maleic anhydride (PE-g-MA) on thermal properties, morphology, and tensile properties of low-density polyethylene (LDPE) and corn starch blends. Journal of Applied Polymer Science, 88(13), 2904-2911.

$\mathrm{Lu}$, J.Z., Wu, Q., Negulescu, I.I. (2005). Wood-fiber/high-density-polyethylene composites: Coupling agent performance. Journal of Applied Polymer Science, 96(1), 93-102.

Lu, J.Z., Wu, Q., McNabb, H.S. (2000). Chemical coupling in wood fiber and polymer composites: a review of coupling agents and treatments. Wood and Fiber Science, 32(1), 88-104.

Markarian, J. (2005). Wood-plastic composites: Current trends in materials and processing. Plastics, Additives and Compounding, 7(5), 20-26.

Mngomezulu, M.E., John, M.J., Jacobs, V., Luyt, A.S. (2014). Review on flammability of biofibres and biocomposites. Carbohydrate Polymers, 111, 149-182.

Ndiaye, D., Fanton, E., Morlat-Therias, S., Tidjani, A., Gardette, J.L. (2008). Durability of wood polymer composites: Part 1. Influence of wood on the photochemical properties. Composites Science and Technology, 68(13), 27792784.

Ndiaye, D., Tidjani, A. (2012). Effects of coupling agents on thermal behavior and mechanical properties of wood flour/polypropylene composites. Journal of Composite Materials, 46(24), 30673075 .
Nikolaeva, M., Kärki, T.I.M.O. (2011). A review of fire retardant processes and chemistry, with discussion of the case of wood-plastic composites. Baltic For, 17(2), 314-326.

Nourbakhsh, A., Ashori, A. (2009). Preparation and properties of wood plastic composites made of recycled high-density polyethylene. Journal of Composite Materials, 43(8), 877-883.

Özmen, N., Çetin, N., Narlıoğlu, N., Çavuş, V., Altuntaş, E. (2014). MDF atıklarının odun plastik kompozitlerin üretiminde değerlendirilmesi. Turkish Journal of Forestry, 15(1), 65-71.

Pan, M., Mei, C., Du, J., Li, G. (2014). Synergistic effect of nano silicon dioxide and ammonium polyphosphate on flame retardancy of wood fiber-polyethylene composites. Composites Part A: Applied Science and Manufacturing, 66, 128-134.

Panthapulakkal, S., Zereshkian, A., Sain, M. (2006). Preparation and characterization of wheat straw fibers for reinforcing application in injection molded thermoplastic composites. Bioresource Technology, 97(2), 265-272.

Sain, M., Park, S.H., Suhara, F., Law, S. (2004). Flame retardant and mechanical properties of natural fibre-PP composites containing magnesium hydroxide. Polymer Degradation and Stability, 83(2), 363-367.

Senesi, N., D'orazio, V., Ricca, G. (2003). Humic acids in the first generation of EUROSOILS. Geoderma, 116(3), 325344.

Shahid, S. A., Qidwai, A.A., Anwar, F., Ullah, I., Rashid, U. (2012). Effects of a novel poly (AA-co$\mathrm{AAm} / \mathrm{AlZnFe} 2 \mathrm{O} 4 /$ potassium humate superabsorbent hydrogel nanocomposite on water retention of sandy loam soil and wheat seedling growth. Molecules, 17(11), 12587-12602.

Stark, N.M., White, R.H., Mueller, S.A., Osswald, T.A. (2010). Evaluation of various fire retardants for use in wood flour-polyethylene composites. Polymer Degradation and Stability, 95(9), 19031910. 
Stevenson, F.J. (1994). Humus chemistry: genesis, composition, reactions. New Jersey, NJ: John Wiley \& Sons.

Tatzber, M., Stemmer, M., Spiegel, H., Katzlberger, C., Haberhauer, G., Mentler, A., Gerzabek, M.H. (2007). FTIR-spectroscopic characterization of humic acids and humin fractions obtained by advanced $\mathrm{NaOH}, \mathrm{Na}_{4} \mathrm{P}_{2} \mathrm{O}_{7}$, and $\mathrm{Na}_{2} \mathrm{CO}_{3}$ extraction procedures. Journal of
Plant Nutrition and Soil Science, 170(4), 522-529.

Wechsler, A., Hiziroglu, S. (2007). Some of the properties of wood-plastic composites. Building and Environment, 42(7), 2637-2644.

Wei, L., McDonald, A.G., Freitag, C., Morrell, J. J. (2013). Effects of wood fiber esterification on properties, weatherability and biodurability of wood plastic composites. Polymer Degradation and Stability, 98(7), 1348-1361. 